\title{
The effort of counseling guidance teacher in developing student learning motivation
}

\author{
Fahrurrazi $^{{ }^{*}}$, Riska Damayanti ${ }^{2}$ \\ 1,2 Universitas Islam Negeri Sunan Kalijaga, Yogyakarta, Indonesia \\ Email: fahrurrazi824@gmail.com
}

\begin{abstract}
Purpose - This study aims to find out the efforts of guidance and counseling Madrasah Aliyah (MA) Madania teachers in developing students' learning motivation.

Method - This study uses a qualitative approach descriptive. The subjects of this study amounted to 6 people, namely 1 guidance and counseling teacher (BK), and 5 students of MA Madania. The data-collection technique in this study uses observations and interviews.
\end{abstract}

Result - The results showed that the students who had done guidance and counseling realized that learning was important and had undergone changes. The changes were like before, they did not want to learn, when they were asked to study they avoided it, they also did not want to do assignments, and slept when the teacher was explaining and so on. When given counseling guidance, there are changes in which they start to have an effort in learning such as: willing to do assignments, study independently and study in groups with friends.

Implications - The results of this study are expected to be input in improving several things that need to be done by counseling guidance teachers in schools.

Originality - Motivational improvement framework with the efforts of BK MA Madania teachers in developing student learning motivation.

Keywords: Guidance and counseling teacher, motivation, student learning.

For citation: Fahrurrazi, Damayanti, R. (2021). The effort of counseling guidance teacher in developing student learning motivation. Journal of Advanced Guidance and Counseling. 2(1). 72-82. https://doi.org/10.21580/jagc.2021.2.1.8098.

*Corresponding author: Fahrurrazi (fahrurrazi824@gmail.com), Universitas Islam Negeri Sunan Kalijaga. Jl. Laksda Adisucipto, Papringan, Caturtunggal, Kec. Depok, Kabupaten Sleman, Daerah Istimewa Yogyakarta, 55281. 
The effort of counseling guidance teacher in developing student learning motivation

\begin{abstract}
Abstrak
Tujuan - Penelitian ini bertujuan untuk mengetahui upaya guru bimbingan dan konseling Madrasah Aliyah (MA) Madania dalam mengembangkan motivasi belajar siswa.

Metode - Penelitian ini menggunakan pendekatan kualitatif deskriptif. Subyek penelitian ini berjumlah 6 orang yaitu 1 orang guru bimbingan dan konseling (BK), dan 5 orang siswa MA Madania. Teknik pengumpulan data dalam penelitian ini menggunakan observasi dan wawancara.

Hasil - Hasil penelitian menunjukkan bahwa siswa yang telah melakukan bimbingan dan konseling menyadari bahwa belajar itu penting dan telah mengalami perubahan. Perubahannya seperti dulu, mereka tidak mau belajar, ketika diminta untuk belajar mereka menghindarinya, mereka juga tidak mau mengerjakan tugas, dan tidur ketika guru sedang menjelaskan dan sebagainya. Ketika diberikan bimbingan konseling, terjadi perubahan dimana mereka mulai memiliki usaha dalam belajar seperti: mau mengerjakan tugas, belajar mandiri dan belajar berkelompok dengan teman.
\end{abstract}

Implikasi - Hasil penelitian ini diharapkan menjadi input dalam meningkatkan beberapa hal yang perlu dilakukan oleh guru bimbingan konseling di sekolah.

Originalitas - Kerangka peningkatan motivasi dengan upaya guru BK MA Madania dalam mengembangkan motivasi belajar siswa.

Kata kunci: Guru bimbingan dan konseling, motivasi, belajar siswa.

\title{
Introduction
}

Counseling guidance teachers are people who are responsible for providing guidance and counseling in schools or madrasas consciously towards the development of personality and abilities possessed by students (Ramayulis \& Mulyadi, 2016). Guidance and counseling is a process of providing assistance by the counselor to the counselee directly to assist the counselee in overcoming the problem. With the guidance and counseling in schools or madrasas, it is expected to be able to help students in actualizing themselves optimally. By doing this, the students can get better achievements. (Winkel, 2006). To realize and develop the potential possessed by students, the role of guidance and counseling teachers is the most important to develop, foster and solve problems for students. Assistance provided by counseling teachers to students through individual or group guidance services, so that students are able to overcome various difficulties experienced independently. In the problems experienced by MA Madania Yogyakarta students, 
Fahrurrazi, Riska Damayanti

the role of counseling guidance teachers is very urgent to develop student motivation in the learning process at school.

In the process of teaching and learning activities in schools, teachers find JAGC | 74 various characteristics of students. There are types of students who do not have difficulties in learning and the other types of students who have difficulties in learning. Learning difficulties experienced by students are caused by the lack of students' motivation. Hence, students' motivation in learning is very important so that the learning process runs well and perfectly (Amani, 2018).

Learning is due to the interaction between stimulus and response (Slavin, 2000). While motivation is an effort based on actions that direct and maintain a person's behavior to act to do something in order to get certain results or goals (Hamzah, 2011). In a broader sense, motivation is something that encourages the emergence of an action, directs the action to the achievement of the desired goal, and determines the sooner or later the action. Motivation should be considered as something related to needs, meaning that individuals have the drive to fulfill their needs. (Hamalik, 2002). In this manner, what is meant by learning motivation is the tendency of students to carry out learning activities that are driven by a desire to achieve the best possible achievement and learning outcomes.

In the process of learning activities, motivation is needed to encourage students to learn. A person who has motivation consists of a tendency to complete difficult tasks but not commensurate with his level of ability, a desire to try and work independently and find his own solutions, a strong desire to move forward and achieve more success than previous achievements, future orientation and persistence at work. As the result, the learning motivation possessed by students can strengthen the spirit of students in learning and raise students' attention so that they have strong desire to learn (Zarniati et al., 2014).

In general, there are two factors that influence student learning motivation, namely, internal and external factors. What is meant by internal factors are active forces without the need for external stimuli, because each individual has the urge to do something. Meanwhile, what is meant by external factors are active forces obtained from external stimuli, such as the method used by educators to increase 
The effort of counseling guidance teacher in developing student learning motivation

student learning motivation (Djamarah, 2000). Meanwhile, in a more detailed perspective, the factors that influence student learning motivation are the ideals or aspirations, abilities, conditions of the family environment, community environment and school environment (Masni, 2015).

The problems found in MA Madania Yogyakarta based on the results of JAGC | 75 observations and interviews conducted with counseling guidance teachers showed that some students who experienced low learning motivation such as not wanting to learn, when they were told to study, they even avoided to do that, not wanting to do assignments and sleeping when the teacher is explaining. Here, the factor causing the low motivation of students in MA Madania is due to family factor. The case is that the students who study at the madrasa are children who are abandoned by their parents, orphans and children who do not have families. To prevent or even to overcome such problems, it requires the attention of the counseling guidance teacher. The role and existence of the counseling guidance teacher is very important in order to assist students in overcoming the problems they face, especially related to student learning motivation so that students are able to achieve the expected goals. In overcoming the low learning motivation of students, it is very necessary to cooperate between counseling guidance teachers and subject teachers. Hence, the formulation of the problem in this study is how the efforts made by counseling teachers in developing student motivation at MA Madania Yogyakarta.

\section{Research Method}

This research is a field research, using descriptive qualitative as its approach. Descriptive approach is a qualitative approach in the form of words or pictures and someone's behavior that can be observed (Moleong, 2007).

The subjects in this study were six people. It consists of one person who is a teacher of counseling guidance and five others who are students of Madrasah Aliyah (SMA) Madania. With an agreement to include the initial-name in order to maintain the identity and confidentiality of the subject. This research was carried out in depth and comprehensively which was obtained related to the efforts of counseling guidance teachers in increasing students' learning motivation. All 
Fahrurrazi, Riska Damayanti

subjects are a unit consisting of teachers and students with the availability to explore the data in depth. In this study, the teacher is the primary data source while the students are the secondary data source.

The data collection techniques in this study used interviews and observations (Jhon W. Creswell, 2019). Data were obtained through interviews conducted directly with six informants who were teachers and students. The reason of the researcher chose the six informants was because they were interrelated with each other. The location of this research was carried out in one of the madrasas in Yogyakarta, namely Madrasah Aliyah Madania. The time allocation for the research was approximately one month. The Interviews were conducted in a natural and structured manner to maintain the comfort and confidentiality of the subjects. The things that were interviewed were related to the efforts of counseling guidance teachers in increasing students' learning motivation. While the observations made on the participants aim to observe the counseling process carried out by the counseling guidance teacher to his students who have a lack of motivation to learn. Data analysis carried out in this study was data reduction, data presentation, and data verification (Matthew B. \& Huberman, 1994).

\section{Results and Discussion}

This section described the results of the research conducted at MA Madania Yogyakarta, it is about the efforts of counseling guidance teachers in developing learning motivation of class X Ma Madania students.

MA Madania is a madrasah (type of islamic school) that specifically accommodates children who have problems such as being abandoned by their parents, orphans, and children who do not have families, therefore they are psychologically disturbed and Mostly, the students have not accepted the situation so they have no motivation, one of which is the problem of lack of motivation in learning. The subjects of this study were 6 people with the initials TS, DW, AZ, WK, FR, BM. The primary subject in this study is TS, TS is a counselor or a counseling guidance teacher in MA Madania who has worked or has been teaching in $\mathrm{Ma}$ Madania for 1 year. TS is also an alumni of MA Madania, and TS finished Master degree in one of the State Campuses in Yogyakarta. Furthermore, DW, AZ, WK, FR, 
The effort of counseling guidance teacher in developing student learning motivation

BM are secondary subjects in this study. The five secondary subjects are class $X$ students who have low motivation in learning.

In developing student learning motivation, the efforts made by Guidance Counseling teachers as follows:

"Usually I motivate students by giving an understanding that what is the purpose of going to school, who the person that they wants to be happy, which means giving awareness to students, clarifying the goals that students want to achieve, and giving appreciation to students in the form of praise, this is given to students who want and diligent in doing work".

In the other hand, the subject (counseling teacher) also conducts an assessment as described below:

"I also assessed what are the obstacles for students to learn. For example, students from outside Java, such as from East, have language barriers in understanding Indonesian. They are still confused with the Indonesian language, so what I do is to keep communicate using proper Indonesian between students and the counseling teacher, as well as among students and students, so that they get used to it and by the time they will fully understand Indonesian".

Then the Subject (Counseling Guidance Teacher), and some practitioners at school work together to increase study-hours, as stated by the Subject (Counseling Guidance Teacher) below:

"The practitioners at school and I agreed to increase the hours of lessons. All children are gathered in one room and they have to learn, what the subject to learn is not forced to learn certain subject. But they are free to choose learning something or drawing. This means that it remains directed, and monitored by a caregiver or guidance teacher".

Subjects (Counseling Guidance Teachers), and the practitioners at school also cooperate in terms of requiring attendance. As the following research-subject (Counseling Guidance Teacher) said:

"We also require attendance in the student learning process so that those who do not attend will be subject to sanctions". 
Fahrurrazi, Riska Damayanti

Furthermore, the research subject (Counseling Guidance Teacher) and the practitioners at school also work together to change students' learning methods, such as the subject's statement (Counseling Guidance Teacher) as follows:

JAGC $\mid 78$

"We also changed student learning methods, so that students can absorb lessons better. Guidance and counseling teachers and other subject teachers change student learning methods, which are different from before, so that students can absorb lessons better".

Theoretically, indicators of learning motivation arise due to two factors, namely intrinsic and extrinsic factors. Both are caused by certain stimuli that trigger individuals to want learning something more actively and enthusiastically. Intrinsic factors in the form of desire. It is a desire to succeed and encouragement of learning needs and expectations of ideals. While extrinsic factors are the existence of awards, a conducive learning environment and interesting learning activities (Hamzah, 2011). Students will be motivated after doing guidance and counseling, as said by the subject (Counseling Guidance Teacher) that:

"Students are motivated after conducting guidance and counseling for 3 to 4 meetings. Students will be motivated when I am in the process of guidance and counseling services relating to the condition of students, in the counseling process I already have student data such as family and others. Therefore, in the process of doing the counseling service, I usually relate it to the condition of the student's family, so that awareness and change usually arise for students".

The condition of students when motivated is that there have been changes in terms of learning such as doing assignments, willing to study independently or study in groups. The subject (Counseling Guidance Teacher) said that:

"The changes experienced by these students were like before, students did not want to learn, then when they were asked to study, they avoided it, and not doing their homework, and slept when the teacher was explaining, and so on. When given counseling guidance there is a change and they realize that learning is important, students start trying to learn, such as: willing to do assignments, study independently and study in groups with friends. This is in accordance with what all student subjects said that learning is important".

Subject (Student) DW said that: 
The effort of counseling guidance teacher in developing student learning motivation

"Studying is important, both for the present and the future", AZ: "Learning, so that our goals can be achieved". WK: "In order to get good grades", FR: "Learn to gain knowledge and gain insight", BM: "Learning, so that we become smart".

The school system also supports in increasing students' learning motivation. As JAGC | 79 the subject (Counseling Guidance Teacher) said as follows:

"Usually the practitioners at school will hold a teacher meeting, or teacher evaluation once a month, how the children are learning, how the teacher's teaching methods are. And this is directly monitored and evaluated by the MA Madani foundation. Therefore it will be known how the development of students by how the teacher conveys lessons to students. Then the school also usually conducts treatments for children with low motivation in learning, usually the homeroom teacher directly communicates to the counseling guidance teacher, to be immediately handled or given guidance and counseling services."

Constraints of Counseling Guidance Teachers in developing the Learning Motivation of MA Madania students. Subject (Counseling Guidance Teacher) explained that:

"There are several obstacles that I face in developing student motivation as follows":

a. Students who are psychologically disturbed

"So the children or students who enter MA Madania are psychologically disturbed, such as broken homes or their families are not intact, abandoned by their parents, orphans, and others, so to increase their learning motivation, I think it is not that easy.".

b. Problem about Language

"Students who come from outside the Java area, they always use their own local language, and prefer to use it rather than Indonesian, as concequence it is difficult and less fluent to speak Indonesian. With the result, students find it difficult to understand the Indonesian language itself. At the end, it is also difficult to interact with the Guidance Counseling teacher, as well as with other friends. Therefore I have to simplify the Indonesian language to students, so that they can understand. And I (Counseling Guidance Teacher), as well as all the teachers at MA Madania, must communicate intensively with students using Indonesian". 
Fahrurrazi, Riska Damayanti

c. Difficult to adapt to heterogeneous learning styles of students

"The learning style of each student is different, there are students who study usually in a quiet place, some while listening to music. In this case, it cannot be done and will disturb other students if they study while listening to music because all students study in the same place. So adapting their hydrogen learning style seems to me a bit difficult".

The subject's efforts (Counseling Guidance Teachers) in developing student learning motivation such as giving encouragement or motivation, the aim is to provide understanding and awareness to students in accordance with Sudarwan's opinion that motivation is a force, drive, need, spirit, pressure, or psychological mechanism that drives individuals or a group to achieve certain goals (Zarniati et al., 2014). In another perspective, a motivation has a goal of encouraging someone to act, this kind of motivation is as a driving force for every activity that is carried out, guiding the direction and goals to be desired or achieved. It also determines what actions must be done in order to achieve the goal. (Sardiman, 1996). In addition, motivation is extremely important in order to give encouragement to individuals or students in learning activities, this makes a way to give instructions to behavior (Kompri, 2016).

After doing Guidance and Counseling, the students show a change. These changes are like realizing that learning is a crucial aspect, students begin to learn, because they begin to have the desire to do assignments, study independently and study in groups with their friends. The students also said that learning is essensial both for the present and the future, by learning so that we can achieve our goals, by studying so that we can and get good grades, learning to increase knowledge and broaden our horizons, and by studying so that we become smart. So it can be concluded that students already have the drive or motivation to learn and to achieve their goals or to get something they want. This is in accordance with Handoko's opinion that there are several characteristics or indicators to determine the strength or high level of student learning motivation as follows, namely the strong will to do or do something, being smart in doing assignments (Handoko, 1992). Furthermore, according to Sardiman, learning will be successful if students have proper motivation to learn, the characteristics of students who have learning 
The effort of counseling guidance teacher in developing student learning motivation

motivation are as follows: being diligent in doing assignments, not wanting to give up when facing difficulties, showing interest in various problems, more happy to work independently, and happy in finding questions and solving problems (Sardiman, 2006).

Furthermore, according to Sardiman, students who have profound motivation JAGC | 81 are not easily discouraged, often learn independently, and can defend their opinions (Sardiman, 2001). In addition, the subject (student) is encouraged or motivated to do something because they want to achieve certain goals as well. This means that students have extrinsic motivation, which is in accordance with Syaiful's opinion that extrinsic motivation is the desire to achieve something driven because they want to get external rewards or avoid external punishment. A student who has an extrinsic motivation to learn is a student who place their learning goals outside of what they are learning, for example to achieve high scores, degrees and honors (Djamarah, 2000).

\section{Conclusion}

The results of this study show that the inmates of Class IIA Women's Prison in Semarang have coping skills with good categories. The average results of the five indicators, including actively facing problems, planning, reducing competition activities, self-control, and seeking social support are categorized into the good category. The results are influenced by various coaching activities, as well as the culture of life applied in the prison. The results of this study can be used by Class IIA Women's Prison in Semarang in improving and developing the model of coaching, adding facilities and infrastructures such as the addition of more varied reading books, the addition of buildings or rooms, and the addition of officers.

\section{References}

Amani. (2018). Peran guru bimbingan dan konseling dalam memotivasi belajar siswa SMP N 15 Yogyakarta. HISBAH: Jurnal Bimbingan Konseling Dan Dakwah Islam, 15(1), 20-34. https://doi.org/10.14421/hisbah.2018.151-02.

Djamarah, S. B. (2000). Psikologi belajar. PT. Rineka Cipta.

Hamalik, O. (2002). Psikologi belajar dan mengajar. Sinar Baru Algensindo. 
Fahrurrazi, Riska Damayanti

Hamzah, B. U. (2011). Teori motivasi \& pengukurannya. PT. Bumi Aksara.

Handoko, T. H. (1992). Manajemen personal dan sumber daya manusia. Universitas Gajah Mada.

Jhon W. Creswell. (2019). Research design pendekatan metode kualitatif, kuantitatif, dan campuran (ke-IV). Pustaka Pelajar.

Kompri. (2016). Motivasi pembelajaran perspektif guru dan siswa. Rosda Karya.

Masni, H. (2015). Strategi meningkatkan motivasi belajar mahasiswa. Jurnal Dikdaya, 5(1). http://dx.doi.org/10.33087/dikdaya.v5i1.64.

Matthew B., M., \& Huberman, H. (1994). Qualitative data analysis: A sourcebook of new methods. Sage.

Moleong, J. L. (2007). Metode penelitian kualitatif edisi revisi. Rosda Karya.

Ramayulis \& Mulyadi. (2016). Bimbingan konseling di sekolah \& madrasah. Kalam Mulia.

Sardiman, A. M. (1996). Interaksi dan motivasi belajar mengajar pedoman bagi guru dan calon guru. Rajawali Pers.

Sardiman, A. M. (2001). Interaksi dan motivasi belajar mengajar. Raja Grafindo Persada.

Sardiman, A. M. (2006). Integrasi dan motivasi belajar. Raja Grafindo Persada.

Slavin, R. E. (2000). Educational psychology: Theory and Practice. Allyn and Bacon.

Winkel, W. S. (2006). Bimbingan dan konseling di instituti pendidikan. Media Abadi.

Zarniati, Alizamar, \& Zikra. (2014). Upaya guru bimbingan dan konseling dalam meningkatkan kegiatan belajar peserta didik. Konselor, 3(1). https://doi.org/10.24036/02014312975-0-00. 